\title{
塑性域から座屈域にわたる大変位の繰り返しを 受ける異形鉄筋の破壊条件に関する研究
}

\author{
桧貝 勇 $^{1} \cdot$ 中村 光 $^{2} \cdot$ 斉藤成彦 $^{3}$ \\ ${ }^{1}$ 正会員 工博 山梨大学教授 工学部土木環境工学科（テ400-8511 山梨県甲府市武田4-3-1 1 ) \\ E-mail: higai@yamanashi.ac.jp \\ 2 正会員 工博 名古屋大学大学院助教授 工学研究科土木工学専攻 \\ ( ( 463-8603 名古屋市千種区不老町) \\ ${ }^{3}$ 正会員 工博 山梨大学助教授 工学部土木環境工学科
}

\begin{abstract}
R C 部材の変形能力を大きくして耐震性を向上させる目的で，多量の横方向鉄筋を密に配置することが 一般的になってきている。このようにすれば軸方向鉄筋の弾性座屈は防止できるが，鉄筋降伏以後の塑性 座屈を防止することは困難である，従って，強震時において軸方向鉄筋は引張塑性域から圧縮座屈域にわ たる変位の繰り返しを受けることになり，低サイクル疲労による鉄筋の破断が懸念される．本研究は，D19 異形鉄笳に強震時を想定した大変位の繰り返し載荷を行って，その破壊条件を検討したものである.
\end{abstract}

Key Words : low cycle fatigue, deformed bars, plastic strain, buckling, failure criterion

\section{1. はじめに}

兵庫県南部地震クラスの大地震に対して R C 構造 物の崩壊を防止するためには，例えば単一柱式橋脚 であれば変位勒性率 10 程度の, 従来の常識を超える 大きな変形能力を付与する必要があり, そのために は，せん断破壊を防止して曲げ型の破壊に誘導寸る こと，さらに，曲げ破壊においても，帯鉄筋などの 横方向筋を密に配置することによって，軸方向鉄筋 の早期座屈を防止すると同時に, 圧縮部コンクリー 卜の拘束を強化してピーク応力以後の軟化を軽減寸 るのが効果的であること，などが明らかにされ，新 しい耐震設計はそのような方向に向かっている.

横方向鉄筋を多量にかつ密に配置すれば，軸方向 鉄筋の支持間隔が短くなるので，弾性座屈は完全に 防止できる。しかし，横方向の支持間隔を極端に小 さくしない限り, 鉄筋降伏以後の塑性座屈を防止す ることは困難である。ささらに，短い座屈長で座屈し た鉄筋では，断面の曲率が著しく増加するので，少 ない回数の繰り返し載荷によって脆性的な破断を生 ずることも懸念される. 実際, 近年行われている, 多量の横方向鉄筋を配置した R C 柱部材の耐震性確 認実験においても，乙のような事実が確認されてい
る。

軸方向鉄筋の破断は構造物の倒壊をもたらすもの であり，絶対に避けなければならない。しかし，コ ンクリート中に配置された鉄筋の座屈性状, 座屈し た鉄筋の破壊条件などに関する研究は内外を問わず ほとんど行われておらず， R C 構造物の耐震設計に 適用できるような状態ではない.

本研究は，地震時における軸方向鉄筋の低サイク ル疲労破壊条件を明らかにすることを最終目的とし て実施したものである。まず，油圧チャックを備え た疲労試験機を用いて，固定長さを変化させた異形 鉄笳に，塑性域の引張から座屈域の圧縮にわたる強 制変位の繰り返し載荷試験を行って, 一定変位の繰 り返しに対する破壊条件を検討した。さらに，地震 時における載荷条件を簡単に近似した，変動する変 位による繰り返し載荷試験を行って，ランダム波形 に対する破壊条件についても検討を行った.

\section{2. 実験方法}

\section{（1）実験の概要}

実験に用いた鉄筋は，ふし間隔 $10 \mathrm{~mm} の$ 直角ふし型 
異形鉄筋 D19 で，その力学的性質は表一 1 のとおり である. 載荷には油圧サーボ式疲労試験機を用いた。 この試験機は最大荷重 $200 \mathrm{kN}$ の油圧チャックを備え ており，鉄筋の圧縮試験および引張試験が可能であ る.

\section{a ) 一定変位振幅の繰り返し載荷試験 (Aシリーズ)}

鉄筋を上下の油圧チャックで固定し, 正負に交番 する強制変位を繰り返し載荷することにより破断さ せた，実験におけるパラメータは，鉄筋の固定長 $l(18 \mathrm{~d}, 12 \mathrm{~d}, 6 \mathrm{~d}, \mathrm{~d}:$ 鉄筋公称直径) と, ピーク変位 時における平均ひずみ（引張を十とする）である.

土木学会コンクリート標準示方書耐震設計編 ${ }^{1)}$ で は, 軸方向鉄筋には直径の 12 倍以下の間隔で横方向 鉄筋を配置することが規定されているので, 本実験 における鉄筋の固定長はこれを考慮して定めたもの である.また強制変位の大きさについては, 最大引 張変位時の平均ひずみ $\left(\varepsilon_{\mathrm{t}}\right.$ : 以後, ピーク引張ひず みという）を $0 \sim 20,000 \mu$, 最大圧縮変位時の平均 ひずみ（ $\varepsilon_{\mathrm{c}}$ : 以後, ピーク圧縮ひずみという）を $-13,000 \sim-54,000 \mu$ の範囲で, 鉄筋破断までの繰り 返し載荷回数が約 40 回以下となるように試的に決 定した (表一2参照).

載荷試験は変位制御で行ったが，まず，第 1 サイ クルは静的載荷とし, その後は, 鉄筋が破断するま で載荷速度を $0.1 \mathrm{~Hz}$ とした正弦波形による動的載荷 を行った。

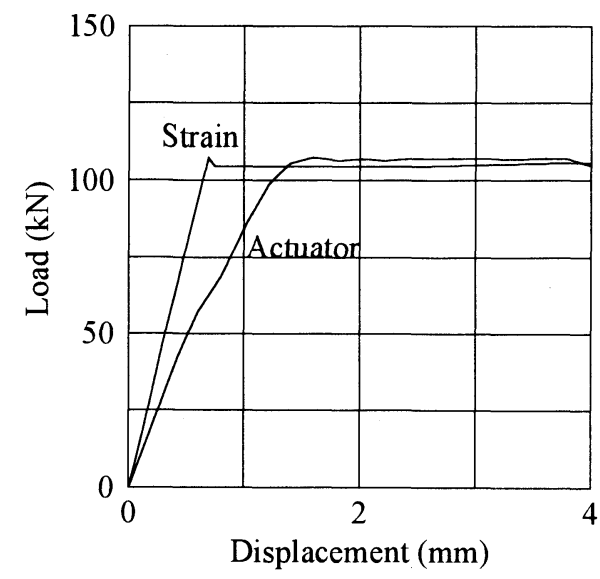

图ー1 鉄筋変形とアクチュエータ変位

表一 1 鉄筋の力学的性質

\begin{tabular}{|c|c|c|c|}
\hline シリーズ & $\begin{array}{c}\text { 降伏点 } \\
\mathrm{N} / \mathrm{mm}^{2}\end{array}$ & $\begin{array}{c}\text { 引張強さ } \\
\mathrm{N} / \mathrm{mm}^{2}\end{array}$ & $\begin{array}{c}\text { ヤング係数 } \\
10^{5} \mathrm{~N} / \mathrm{mm}^{2}\end{array}$ \\
\hline $\mathrm{A}$ & 359 & - & 1.78 \\
\hline $\mathrm{B}$ & 372 & 575 & 1.79 \\
\hline
\end{tabular}

\section{b ）変動する変位振幅による綝り返し載荷試験}

(Bシリーズ)

このシリーズでは，鉄筋の固定長は $18 \mathrm{~d}$ のみとし た. 強制変位に関しては, ピーク引張ひずみ〜ピー ク圧縮ひずみを $10,000 〜-25,000 \mu, 10,000$ $-50,000 \mu, 20,000 \sim-35,000 \mu, 30,000 \sim-25000 \mu$ とした 4 つの基本条件を, ランダムな順番で組み合 わせた 6 種の載荷パターンを用いた.

この場合も, 变位制御で, 第 1 サイクルは静的載 荷とし, 第 2 サイクル以後は, 載荷速度を $0.1 \mathrm{~Hz}$ と した三角波による動的載荷を行った。

\section{（2）鉄筋変形の計測方法の検討}

図一 1 は, 鉄筋の固定長を $18 \mathrm{~d}(18 \times 19.1=343.8 \mathrm{~mm})$ とした場合の引張試験結果を示したものである。疲 労試験機のアクチュエータ変位 (Actuator) は, 鉄 筋中央に貼付けた 2 枚のひずみゲージで測定したひ ずみから計算した変位（Strain）の 2 倍程度と大き く異なっており, アクチュエータ変位によって鉄筋 の変形を測定することはできないことが分かった.

詳細は省略するが， 7 個の変位計を用いて同様の引 張試験を行い, アクチュエータ変位と鉄筋の伸びが 大きく異なる原因を検討したところ，誤差の約 $40 \%$ は，上下チャック自体の動きによるものであり，残 りの約 $60 \%$ は，チャックからの鉄筋の寸心゙り，およ び, チャックの歯と接触している部位での鉄筋の弾 塑性変形によるものであることが分かった。

これらの結果を考慮して，図一2に示寸ような計 測方法を考案した。原理的に言えば，まず，上下の チャックの直近に，それぞれ計測用の鋼製リングを ネジ止めする．つぎに，上のリングに固定したフレ キシブルなワイヤーを下のリングに取り付けられて いるプラスチックのローラーを介して, 変位計 $\mathrm{A} に$

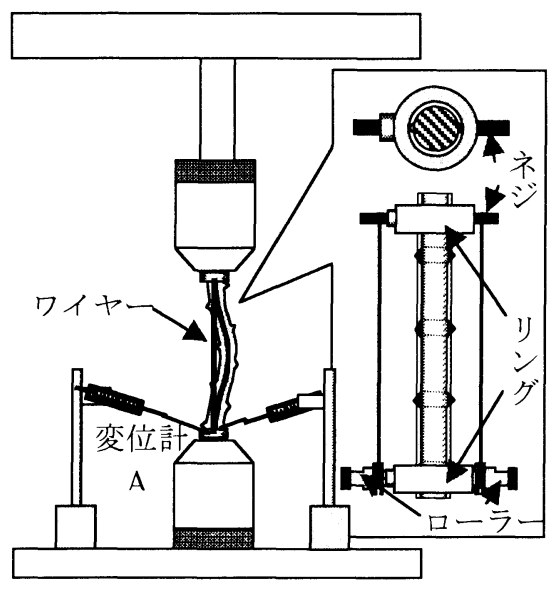

図一２軸方向変形の計測方法 
張力がかかった状態で接続する。この変位計によっ て，上下リング間の距離の変化，寸なわち鉄筋の変 形を計測する方法である。ただし，実際には，下記 のようないくつかの細かい配慮が必要であった。

リングを鉄筋に単にネジ止めしたのでは，引張塑 性域で鉄筋が細くなったときに緩んでしまい，正確 な計測は困難である.そこで, 図一3に示すように， リングの取り付けネジを常にバネで押寸ことにより， 引張塑性域でも緩みのでない構造とした。バネの自 由長は約 $14 \mathrm{~mm}$ ，バネ係数は約 $50 \mathrm{~N} / \mathrm{mm}$ である。この ようにしても，変位計Aは試験機の床に固定されて いるため，下側チャックに動きがあると計測誤差が 生ずることになる。これを避けるために，図ー4に 示寸ように，下側の計測リングに固定した別のワイ ヤーを変位計Bに接続して，下側リングの動きを補 正することとした，なお，リングから変位計までの ワイヤーの長さ及び角度は，変位計 $\mathrm{A}, \mathrm{B}$ について 同一となるようにする必要がある。また, ワイヤー はフレキシブルで伸びのない物が望ましいので，外 径 $0.5 \mathrm{~mm}$ の鋼ワイヤーストランドを用いた.さらに, 計測時におけるワイヤーの伸びを極力小さくするた めに，破断応力近くまでプレロードしたものを使用 している.

図一5 は，上記の方法を用いて鉄筋の引張変形を 計測した例である. 提案方法による結果 (Proposed) が破線で, 確認のために上下リングの変位を別に取 り付けた 2 個の変位計で直接測定した結果 (LVDT) が実線で示されている，繰り返しも含めて約 $6 \%$ の 大ひずみまで，精度の良い計測が可能であることが 分かる.このような比較は, 引張側においては可能 であるが，座屈域に達する圧縮側では，チャックの 間隔が短くなるので変位計のセットが困難であるこ と, また, 鉄筋の座屈方向が一定でないため座屈し た鉄筋が変位計に当たるなど，計測上の困難が多い ため，圧縮側でのキャリブレーションは行なえなか った.

\section{3.一定振幅の繰り返し載荷を受ける異形鉄筋 の疲労破断}

\section{（1）破壊性状}

鉄筋の固定長 /を $18 \mathrm{~d} ， 12 \mathrm{~d} ， 6 \mathrm{~d}$ とし，それぞれに ついて，ピーク引張ひずみ（ $\left.\varepsilon_{t}\right)$ とピーク圧縮ひず み $\left(\varepsilon_{c}\right)$ の值を変化させた $7 \sim 8$ 種の条件で繰り返 し載荷試験を実施した. 各条件に対して, 少なくと も3体以上の供試体の実験を行ったのであるが，実 験後に変形データの精查を行い, 例えば, 左右の変 位計の測定值が著しく異なる，あるいは，アクチュ

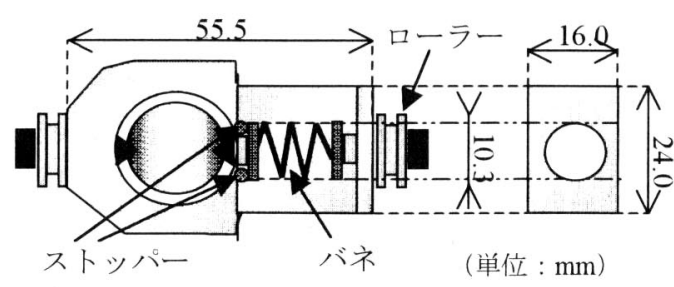

図ー3計測リング

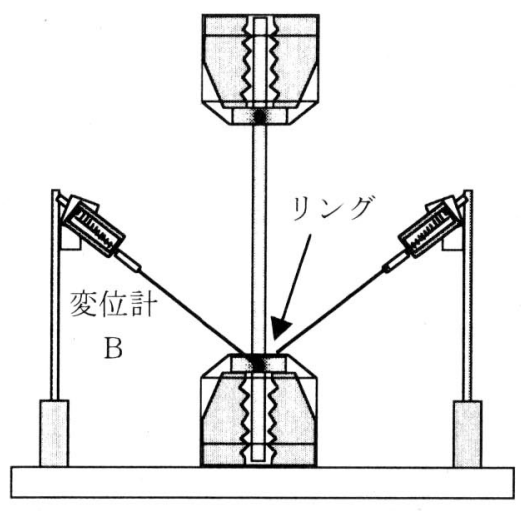

図－4 補正用の変位計測

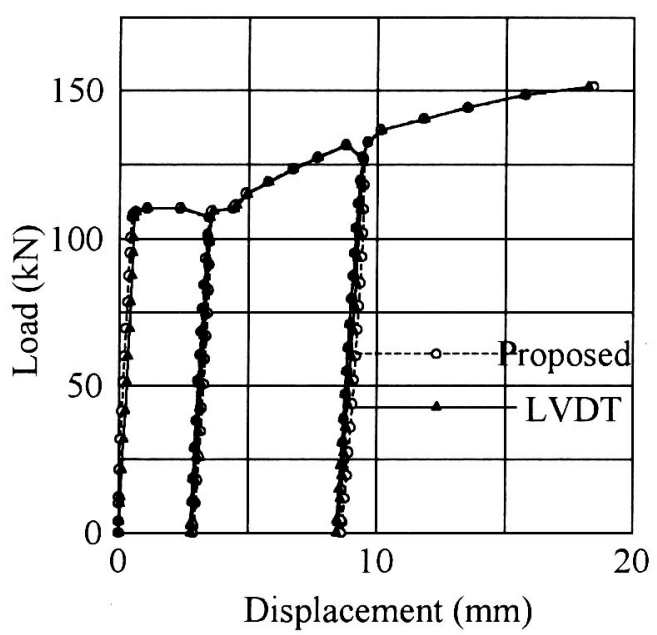

図-5 軸方向変形の計測結果

エー夕変位と鉄筋の変形の相互関係が他の供試体と は大きく異なるなど，問題があると思われるものを 除外したため, 条件によっては供試体数が $1 \sim 2$ 上 なったものもある. 実験の概要は，表一2に示した。

図一6および7は，各供試体の荷重〜軸方向変形 を示したもので, 図一6は固定長 $18 \mathrm{~d}$ の載荷条件 4 ， 図ー7は6dの条件 3 についての例である.

固定長が $18 \mathrm{~d}$ 上長い場合には，第1サイクルにお いて, 塑性域の引張載荷後に除荷し, さらに圧縮力 
表－2 一定振幅による実験の概要

( 歪夕 : $10^{-6}$ )

\begin{tabular}{|c|c|c|c|c|c|c|c|c|}
\hline \multirow{2}{*}{$\begin{array}{l}\text { 固定 } \\
\text { 長 }\end{array}$} & \multirow{2}{*}{$\begin{array}{l}\text { 載 荷 } \\
\text { 条 件 }\end{array}$} & \multicolumn{2}{|c|}{ ピーク歪目標值 } & \multicolumn{2}{|c|}{ ピーク歪実測平均值 } & \multirow{2}{*}{$\begin{array}{l}\text { 供 試 } \\
\text { 体 数 }\end{array}$} & \multicolumn{2}{|c|}{ 破断時のサイクル数 } \\
\hline & & 引張 & 圧縮 & 引張 & 圧縮 & & 各供試体 & 平均值 \\
\hline \multirow{7}{*}{$18 \mathrm{~d}$} & 1 & 0 & -49000 & -2800 & -50300 & 4 & $20,28,24,25$ & 24.3 \\
\hline & 2 & \multirow{3}{*}{9000} & -25000 & 8900 & -28500 & 3 & $34,25,32$ & 31.0 \\
\hline & 3 & & -35000 & 8100 & -36700 & 4 & $25,25,19,33$ & 25.5 \\
\hline & 4 & & -50000 & 8400 & -52300 & 6 & $14,15,17,15,14,12$ & 14.5 \\
\hline & 5 & \multirow{3}{*}{20000} & -29000 & 19600 & -31400 & 5 & $26,24,23,25,28$ & 25.2 \\
\hline & 6 & & -40000 & 20500 & -41400 & 3 & $18,15,17$ & 16. 7 \\
\hline & 7 & & -54000 & 19800 & -56700 & 6 & $13,14,9,12,13,18$ & 13.2 \\
\hline \multirow{8}{*}{$12 \mathrm{~d}$} & 1 & 0 & -44000 & -5600 & -48900 & 2 & 17,19 & 18.0 \\
\hline & 2 & \multirow{3}{*}{8000} & -20000 & 9000 & -21300 & 2 & 16,31 & 23.5 \\
\hline & 3 & & -29000 & 7600 & -32300 & 1 & 23 & 23.0 \\
\hline & 4 & & -45000 & 7500 & -49200 & 4 & $10,10,9,9$ & 9.5 \\
\hline & 5 & \multirow{4}{*}{18000} & -20000 & 14200 & -23700 & 1 & 25 & 25.0 \\
\hline & 6 & & -29000 & 16800 & -33000 & 3 & $15,13,13$ & 13.7 \\
\hline & 7 & & -45000 & 13800 & -46500 & 1 & 10 & 10.0 \\
\hline & 8 & & -52000 & 18500 & -55700 & 3 & $6,6,5$ & 5.7 \\
\hline \multirow{8}{*}{$6 \mathrm{~d}$} & 1 & 0 & -35000 & -12400 & -46100 & 3 & $25,31,32$ & 29.3 \\
\hline & 2 & \multirow{3}{*}{6000} & -20000 & 3200 & -29700 & 2 & 37,24 & 30.5 \\
\hline & 3 & & -24000 & 3400 & -32000 & 4 & $18,20,17,14$ & 17.3 \\
\hline & 4 & & -35000 & 1200 & -38800 & 1 & 10 & 10.0 \\
\hline & 5 & \multirow{4}{*}{13000} & -13000 & 9300 & -22200 & 4 & $19,29,26,19$ & 23.3 \\
\hline & 6 & & -20000 & 7600 & -29800 & 2 & 24,17 & 20.5 \\
\hline & 7 & & -26000 & 9800 & -35300 & 1 & 8 & 8.0 \\
\hline & 8 & & -35000 & 8700 & -45100 & 2 & 7,10 & 8.5 \\
\hline
\end{tabular}

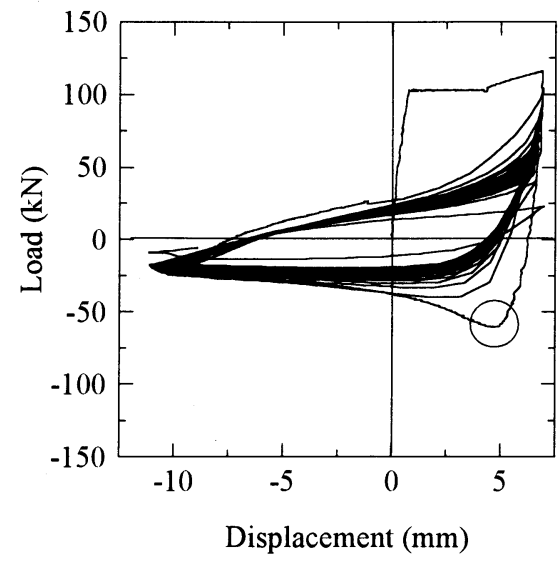

図-6 荷重～変位曲線 $(\mathrm{l} / \mathrm{d}=18)$

が載荷された段階で，降伏荷重以下の荷重によって (図中の丸印) 弾性座屈を生じ，乙れ以後は，圧縮 変位の増加に伴って圧縮力は徐々に低下している. 第 2 サイクル以後は, サイクル数の増加に伴って, 引張ピーク変位時の荷重および圧縮側の最大荷重が

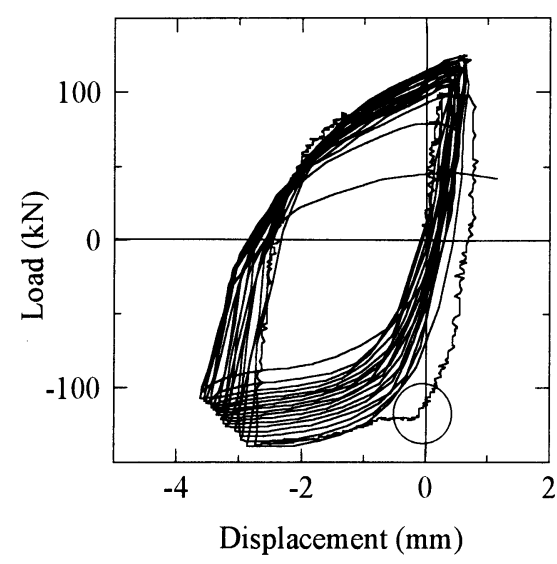

图-7 荷重～変位曲線 $(\mathrm{V} / \mathrm{d}=6)$

徐々に低下しつつ，次第に安定したループに移行し ている.

一方，固定長が $6 \mathrm{~d}$ と短い場合は，1 サイクル目の 圧縮側で，圧縮力が降伏荷重に達した後に（図中の 丸印）横方向のたわみが急増して塑性座屈を生じた 
のであるが，その後ひずみ硬化により荷重はさらに 増加している. 第 2 サイクル以後, サイクル数の増 加に伴って, 引張, 圧縮とも, ピーク変位時の荷重 は徐々に低下している，全体に履歴ループは紡鍾型 でエネルギー吸収の大きい形である.

固定長が $12 \mathrm{~d}$ の場合は，上記両者の中間的な挙動 であるが，弾性座屈を生じており，18d の場合によ り近い性状である。

いずれの場合にも，図一8に概念的に示したよう に, 座屈はリブとほぼ直交する方向に生じた.また, 座屈した鉄筋の圧縮側（四側）からクラックが発生 し，それが徐々に進展して破断に至ることが分かっ た。圧縮側からクラックが発生寸るのは，圧縮縁に おけるひずみ振幅が，引張縁のそれを上回るためで あると考えられる。

\section{（2）破壊条件の検討}

図一 9 は, ピーク変位時の平均ひずみ $\varepsilon_{\mathrm{c}}, \varepsilon_{\mathrm{t}}$ の目 標值と，破断までの繰り返しサイクル数 N の関係を 示したものである. 図中の数字はピーク引張ひずみ の目標値である，当然予測されるように， $\varepsilon$ c または $\varepsilon_{\mathrm{t}}$ の絶対值が大きいほど破断時のサイクル数は減 少している．また，全体的に見ると，鉄筋の固定長 lが短いほど同じピークひずみに対するNは小さくな る傾向が認められる.

そこで, $\mathrm{N} と \varepsilon_{\mathrm{c}}, \varepsilon_{\mathrm{t}}$ の関係を式（1）のように仮 定して, 最小二乗法により各固定長毎に最適な係数 A， B，Cを求めると，図一10のような結果であ り (Aは負の值), 平均ひずみの効果は $l / d$ の值によ つて異なること, また， $\varepsilon_{\mathrm{c}}$ の効果と $\varepsilon_{\mathrm{t}}$ の効果も同 一ではないことが分かる。 なお，係数 Cは $l / d$ にら ずほぼ一定と見なすことができる．

$$
N=\operatorname{EXP}\left(A \cdot \varepsilon_{t}+B \cdot \varepsilon_{c}+C\right)
$$

これらの結果から，式（2）の関係を仮定して,
再度，最小二乗法による関係式の検討を行った。 なお，式（2）の検討には，表一2に示した 67 デー 夕のほか，実際のひずみと目標ひずみの差が大きか ったけれども，実験としては問題がなかったと判断 される 14 のデータも含めて, 合計 81 の実験データ を用いた。また， $\varepsilon_{\mathrm{c}}$ および $\varepsilon_{\mathrm{t}}$ も目標值ではなく， 個々の供試体における各サイクルの実測值の平均值 を用いることとした。

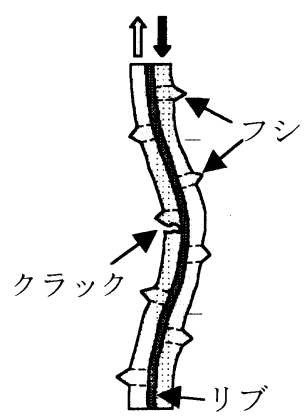

図-8 破断状況

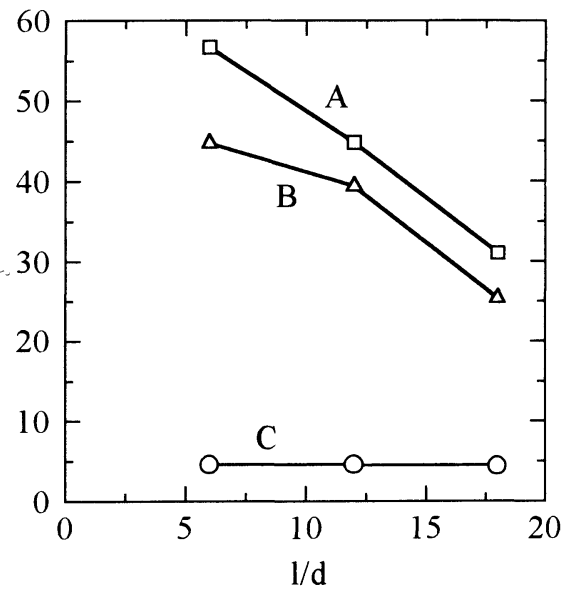

図-10 式 (1) の係数
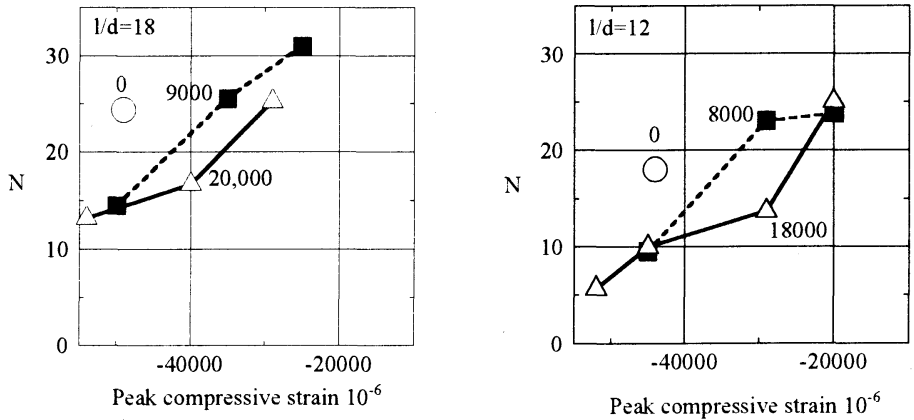

図ー9ピークひずみと破断回数の関係

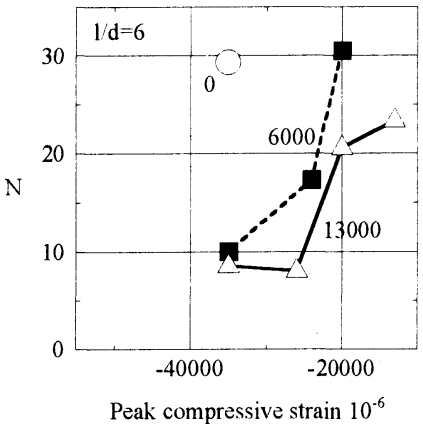

Peak compressive strain $10^{-6}$ 
表-3 破断回数推定式の適合性

\begin{tabular}{|l|l|l|l|l|}
\hline & \multicolumn{1}{|c|}{$18 \mathrm{~d}$} & \multicolumn{1}{|c|}{$12 \mathrm{~d}$} & \multicolumn{1}{|c|}{$6 \mathrm{~d}$} & \multicolumn{1}{|c|}{ 体 } \\
\hline 供試体数 $\mathrm{n}$ & 41 & 19 & 21 & 81 \\
\hline 平均値 & 1.02 & 1.14 & 1.08 & 1.06 \\
\hline 標準偏差 & 0.216 & 0.253 & 0.324 & 0.262 \\
\hline 変動係数 \% & 21.3 & 22.1 & 30.0 & 24.7 \\
\hline
\end{tabular}

$$
N=\operatorname{EXP}\left\{\left(A \cdot \frac{l}{d}+B\right) \varepsilon_{t}-\left(C \cdot \frac{l}{d}+D\right) \varepsilon_{c}+E\right\}
$$

このようにして得られた最適な倸数は， $A=2.019$, $\mathrm{B}=-67.61, \mathrm{C}=1.254, \mathrm{D}=-49.55, \mathrm{E}=4.502$ である.

式（2）による破断回数の計算值 $\mathrm{N}_{\text {cal }}$ と，実測值 $\mathrm{N}_{\mathrm{exp}}$ の関係は图ー1 1 および表一 3 に示した。表ー3に 見られるとおり，全データについて，破断回数の計 算値と実測值の比率 $\left(\mathrm{N}_{\mathrm{cal}} / \mathrm{N}_{\mathrm{exp}}\right)$ の平均值は 1.02 で, その変動係数は $24.7 \%$ でる. 推定の適合度（平均 値）は固定長によらずほぼ 1.0 に近く特定の傾向は 認められないが, 変動係数は $6 \mathrm{~d}$ の場合にやや大きく なっており, 塑性座屈域での実験の難しさを示して いるものと思われる。これらの結果は極めて満足な ものとは言えないが，このような複雑な破壊に対す る推定としては悪くない結果であると考えられる.

\section{（3）直径が異なる鉄筋への適用性の考察}

式（2）はD19を用いた実験結果から統計的に導 いたもので，鉄筋径が異なる場合については実験を 行っていない. 我々の研究室では設備の制約により, これ以上太径の鉄筋の実験はできないので，直径が 異なる鉄筋への適用性については解析的に検討する こととした.

すなわち，鉄筋の座屈挙動を，鉄筋をはり要素で モデル化し有限変形理論を適用した有限要素法解析 により検討したのである。ここで，はり要素は，2 節点 12 自由度を有する 3 次元要素とし, ファイバー モデルにより材料非線形性を考慮した。. 各ファイバ 一に用いる鉄筋の応力〜ひずみ関係は，福浦・前川 のモデル ${ }^{2)}$ を用いた。解析は実験における境界条件 考慮して, 両端固定条件とし, 鉄筋端部の軸方向 変位を制御することで行った．また，座屈を生じさ せるために，鉄筋の軸方向中央位置に初期不整量に 相当する微少な水平力を与えた. 解析についての詳 細は文献 ${ }^{3)}$ を参照されたい。この解析により，本実 験のような, 塑性域の引張変形から座屈域の圧縮変 形の繰り返し載荷を受ける鉄筋の挙動が，良い精度 で求められることは既に確認されている.

図ー12 は，D25 を用い， $l / d$ を 18 とした場合に

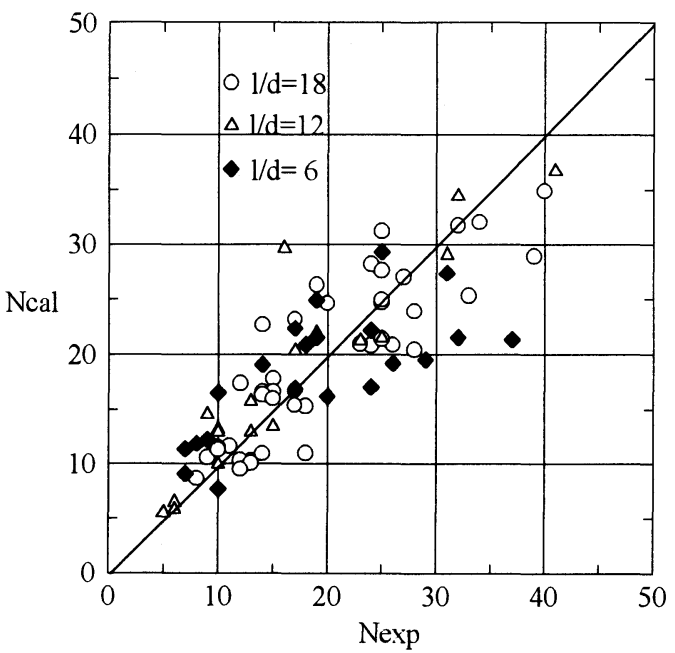

図-11 破断回数の比較

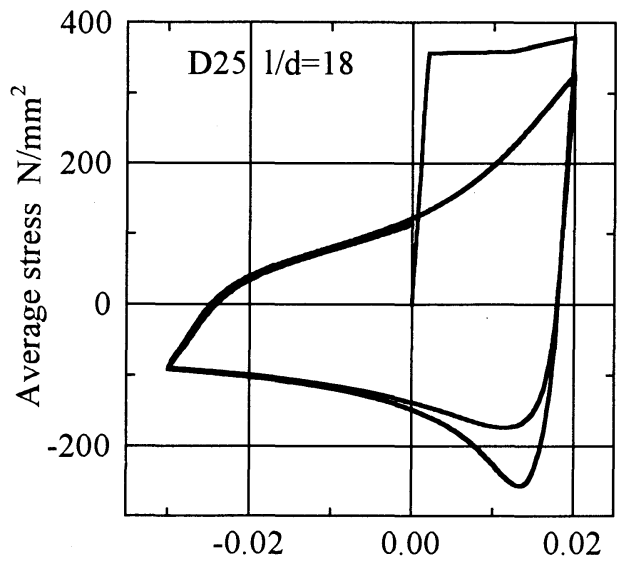

Average strain

図ー12 D 25 の応力〜ひずみ関係

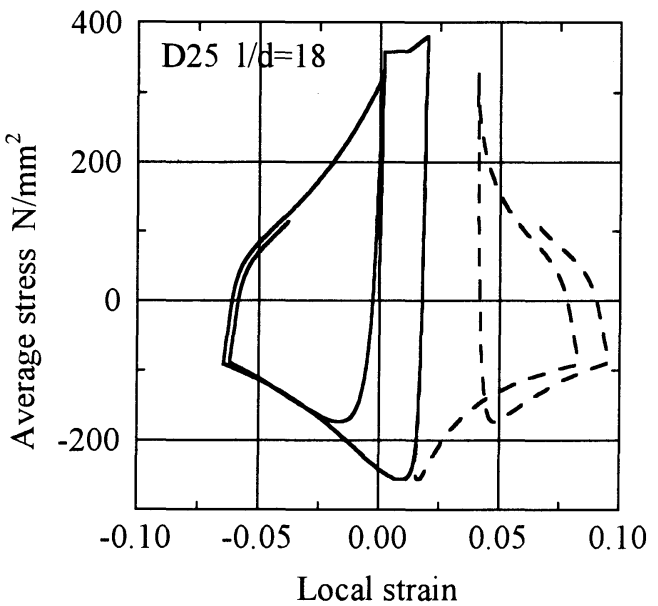

図ー13 D 25 の局所ひずみ 
表-4 4 種類の載荷条件

\begin{tabular}{|c|c|c|c|c|c|c|c|}
\hline \multirow[t]{2}{*}{$\begin{array}{l}\text { 載 } \\
\text { 荷 } \\
\text { 条 件 }\end{array}$} & \multicolumn{2}{|c|}{ ピークひずみ } & \multicolumn{2}{|c|}{ ピークひずみ } & \multicolumn{2}{|c|}{ 破断回数（実験值） } & \multirow{2}{*}{$\begin{array}{c}\text { 破断回数 } \\
\text { (計算值) } \\
\mathrm{N}_{c}\end{array}$} \\
\hline & 引張 & 圧縮 & 引張 & 圧縮 & 各供試体 & 平均值 & \\
\hline 1 & 10000 & -25000 & 6335 & -29235 & $30,34,37,28,29$ & 31.6 & 33.6 \\
\hline 2 & 10000 & -50000 & 8302 & -54549 & $11,16,16,16,13,16,17$ & 15.0 & 16.0 \\
\hline 3 & 20000 & -35000 & 20742 & -39942 & $14,17,17,14,13$ & 15.0 & 16.0 \\
\hline 4 & 30000 & -25000 & 28798 & -28160 & $16,11,13,13,14$ & 13.4 & 17.1 \\
\hline
\end{tabular}

表ー 5 振幅を変化させた実験の概要

\begin{tabular}{|c|c|c|c|c|}
\hline \multirow{2}{*}{ バターン } & 載荷条件の組合せ & \multirow{2}{*}{\begin{tabular}{c} 
破断回数 \\
\cline { 3 - 5 }
\end{tabular}} & & \multicolumn{3}{|c|}{ 累積損傷度 } \\
\cline { 3 - 5 } & & $6-2,6-1,5-3$ & $1.09,1.01,0.94$ & 1.01 \\
\hline $\mathrm{A}$ & $3 \rightarrow 1 \rightarrow 4 \rightarrow 2$ & $5-1,5-4,5-4$ & $0.90,1.06,1.06$ & 1.00 \\
\hline $\mathrm{B}$ & $4 \rightarrow 1 \rightarrow 3 \rightarrow 2$ & $6-1,5-2,6-2$ & $1.08,0.94,1.14$ & 1.05 \\
\hline $\mathrm{C}$ & $4 \rightarrow 3 \rightarrow 1 \rightarrow 2$ & $4-4,5-3,5-3$ & $0.82,0.97,0.97$ & 0.92 \\
\hline $\mathrm{D}$ & $3 \rightarrow 1 \rightarrow 2 \rightarrow 4$ & $5-4,5-1,6-1$ & $1.03,0.88,1.09$ & 1.00 \\
\hline $\mathrm{E}$ & $4 \rightarrow 3 \rightarrow 2 \rightarrow 1$ & $5-1,5-1,4-4$ & $0.85,0.85,0.82$ & 0.84 \\
\hline $\mathrm{F}$ & $1 \rightarrow 4 \rightarrow 3 \rightarrow 2$ & &
\end{tabular}

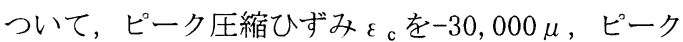
引張ひずみ $\varepsilon_{\mathrm{t}}$ を $20,000 \mu$ とした繰り返し載荷を 2 サイクル与えた時の，鉄筋の平均応力〜平均ひずみ 関係を示したものであり，图一13は，鉄筋軸方向 中央断面での座屈方向の最外縁における局所ひずみ の計算值を示したものである。これらの結果は， $l / d$ および繰り返し載荷における平均ひずみを同一とし た場合の，D19 に対する計算結果と全く同一である ことが確かめられた。このことは，l/d゙同一であれ ば，鉄筋直径にかかわ的ず，平均応力（荷重／鉄筋 断面積）と平均ひずみ（変形／固定長）の関係，お よび，平均応力と局所ひずみの関係が同一であるこ とを意味するので，疲労破壊が鉄筋の局所ひずみの 履歴で定まると寸れば，基本的には直径が異なる鉄 筋に対しても，式（2）の破壊条件が適用できるも のと推察される.ただし, 鉄筋のデフォーメーショ ンの相違によって，ふし周辺における応力集中の程 度が異なること，また，鉄筋の化学成分によって曲 げ戻しに対する耐性が異なると言われていることな ど，解析では考慮されていない要素もあるので，さ らに実験的な検討を要することは言うまでもない.

\section{4. 変位振幅が変化する繰り返し載荷を受ける 異形鉄筋の破断}

\section{（1）載荷条件}

地震時において，例えば， R C 橋脚の軸方向鉄筋 には，ランダムな大きさの強制変形（ひずみ）が繰

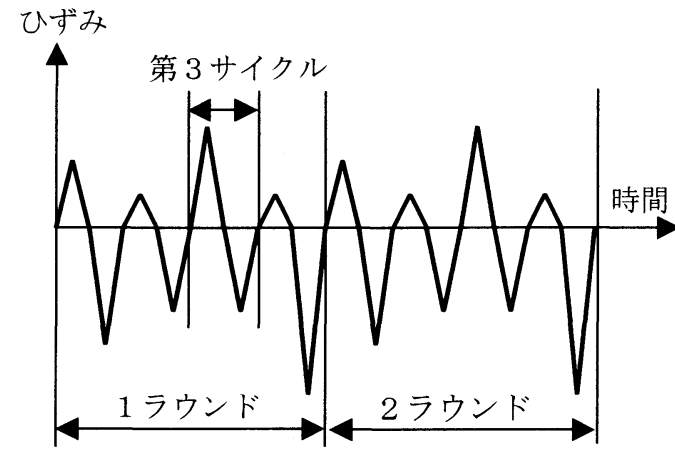

図ー14 ひずみパターン

り返し作用するので，それを近似的に模擬して，変 位振幅が変化する強制変位を作用させる実験を行っ た. 実験では，表一 4 に示すような，ピーク引張ひ ずみを $10,000 〜 30,000 \mu$ ，ピーク圧縮ひずみを $-25,000 \sim-50,000 \mu$ とした 4 種の載荷条件を組み合 わせて用いた。 それぞれ単一の条件で繰り返し載荷 した場合の破断回数は 13〜32 回である.また, 実測 ひずみを用いて，式（2）で算定した破断回数 $\mathrm{N}_{\mathrm{c}}$ も 表中に示した。破断回数の計算值は，条件 4 につい ては実験值 $\mathrm{N}_{\mathrm{e}}$ よりも大きいのであるが，ほぼ実験值 のばらつきの範囲内に含まれており，推定精度に問 題はないと思われる.

繰り返し載荷実験では，これら4つの載荷条件を ランダムな順序で組み合わせた 6 つのパターンを用 いた。 各パターンにおける載荷条件の組み合わせは 表一 5 のとおりである。また，一例として，パター 


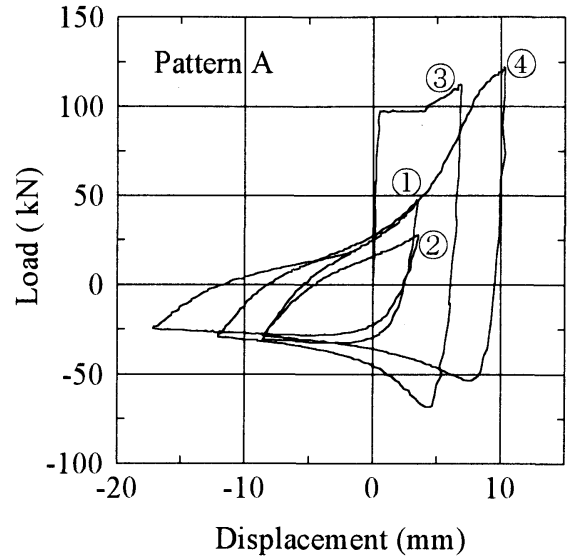

図ー15 パターンA 第 1 ラウンド

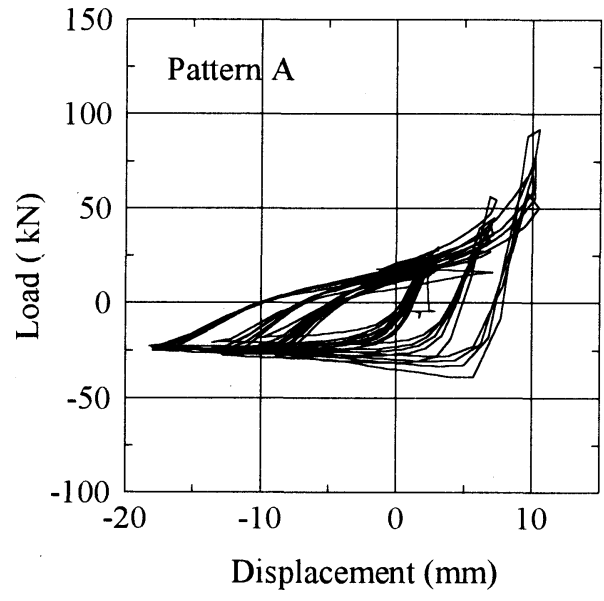

図ー 17 第 2 ラウンド以降 (A)

ンAのひずみ波形を図ー14 に示した。これ以後, 4 つの載荷条件の一巡を「ラウンド」と称し，1つ の載荷条件による載荷を「サイクル」と称すること とする.従って, 1 ラウンドは 4 サイクルからなる.

\section{（2）破壊条件の検討}

各パターンについてそれぞれ 3 体の供試体の実験 を行った．鉄筋が破断した時点は表一 5 に併せて示 したが，例えば， 6-2 とは 6 ラウンドの第 2 サイ クルで破断したことを意味している.

振幅が変化する場合の疲労損傷に関しては, マイ ナー則が成立するかどうかを検討した。すなわち， 一定ひずみ振幅 $\varepsilon_{\mathrm{i}}$ における疲労寿命を $\mathrm{N}_{\mathrm{i}}$ としたと き, $\varepsilon_{\mathrm{i}}$ の $\mathrm{n}_{\mathrm{i}}$ 回の繰り返しによる損傷は $\mathrm{n}_{\mathrm{i}} / \mathrm{N}_{\mathrm{i}}$ であり, これをす心゙ての $\varepsilon_{\mathrm{i}}$ について線形に加算した累積損 傷度 D が 1.0 となったときに疲労破壊寸る, という 考え方である (式 (3) 参照).

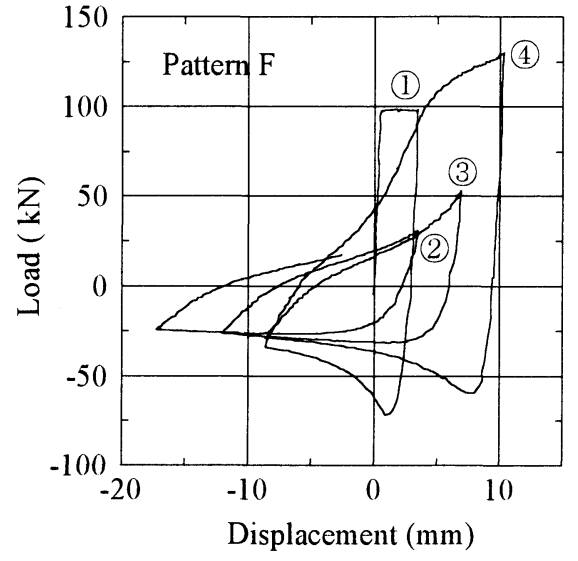

図ー16 パターンF 第 1 ラウンド

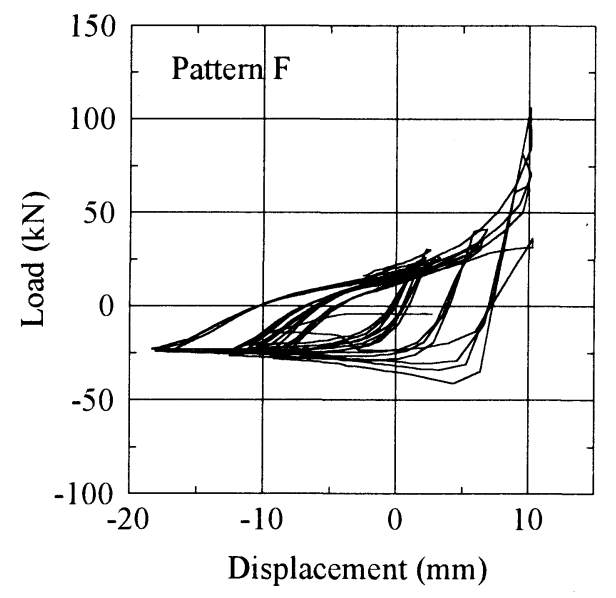

図一 18 第 2 ラウンド以降（F）

$$
D=\Sigma\left(n_{i} / N_{i}\right)=1.0
$$

各供試体の累積疲労損傷度 D は表一5に示した。こ こで, 各載荷条件に対寸る疲労寿命 $\mathrm{N}_{\mathrm{i}}$ は, 第 1 ラウ ンドにおける各サイクルのピークひずみの実測值を 用いて, 式（2）によって算定した值を用いた。 ど のバターンにおいても, 各供試体破断時の累積損傷 度は 0.82 から 1.14 の範囲にあり, 平均的にも 1.0 に近い值であり，マイナー則が良い精度で成立する ことが確認された。

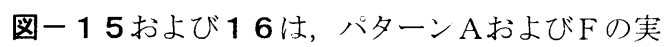
験における第 1 ラウンドの荷重〜軸方向変形を示し たものであり，図中の数字は載荷条件である，載荷 条件の組合せ順序が変わると, 特に引張変形域にお ける荷重〜変形関係はかなり異なっており, 破壊条 件に影響を及ぼすのではないかとの予測も生ずるの 
であるが，図ー 17 および 18 で明らかなように， 第 2 ラウンド以降における荷重〜変形関釈は，載荷 パターンにかかわらずほぼ同様になる。このような 理由で疲労寿命はパターンによらず一定になるもの と考えられるが，大変興味深い結果である.

\section{5. 結 論}

両端を固定した異形鉄筋 D19 が，引張側では降伏 し, 圧縮側では座屈するような大変位の繰り返しに より，低サイクル疲労破断する場合の破壊条件につ いて，主として実験的に検討を行った。

鉄筋のデフォーメーションの影響や, 材質の影響 など, さらに検討を要する問題も残されているが, 本研究で得られた主な結論をとりまとめると以下の とおりである。

(1) 塑性域, 座屈域での鉄筋の変形を計測する方法と して, 鋼リングと鋼ワイヤーを用いる方法を開発し， その有効性を確認した。

(2) 鉄筋の疲労破壊条件を, 鉄筋固定長と鉄筋直径の 比 $(l / d)$, および, ピーク変位時の平均ひずみ $(\varepsilon \mathrm{t}$, $\left.\varepsilon_{\mathrm{c}}\right)$ の関数として示した. 有限要素法による解析の 結果, $l / d$ を一定とすれば, 平均応力と平均ひずみの 関係，および，平均応力と破壊断面の局所ひずみの 関係は，鉄筋直径によらず同一であることが確かめ
られたので，この破壊条件は直径の異なる鉄筋にも 適用できるものと推測される.

(3) 変位振幅が変化するような繰り返し載荷を受け る場合の疲労損傷に関しては, マイナー則が適用で きることが確かめられた。

謝辞 : 本研究の実験は, 当時本学の大学院生, 卒論 生であった, 雨宮明人, 前田 忍, 小林宏崇, 手塚 公宏, 松山昌史の各氏が実施したものである。ここ に謝意を表する次第である.

\section{参考文献}

1) [平成 8 年制定]コンクリート標準示方書, 而震設計編, 土木学会.

2) 福浦尚之, 前川宏一：R C 非線形解析に用い万鉄筋の繰 り返し履歴モデル, 土木学会論文集, No. 564/V-35, pp. 291-295, 1997.

3) 田上和也, 中村 光, 斎藤成彦, 桧貝 勇: 繰り返し荷 重を受ける鉄筋の座屈モデルに関する研究，構造工学 論文集, Vol. 47A, pp. 725-734, 2001.

(2003. 3.31 受付)

\title{
FATIGUE FAILURE CRITERION OF DEFORMED BARS SUBJECTED TO LARGE DEFORMATION IN PLASTIC REGION AND BUCKLING REGION
}

\author{
Takeshi HIGAI, Hikaru NAKAMURA and Shigehiko SAITO
}

\begin{abstract}
After the Hanshin-Awaji earthquake, large amount of lateral reinforcement is commonly used to improve seismic performance of the RC structures. Although large amount of and closely spaced lateral reinforcement will be effective to prevent elastic buckling of the axial reinforcement, it can hardly prevent plastic buckling. Therefore, under strong earthquake, axial reinforcement will be subjected to the repeated loading of large deformation reversals ranging from tensile plastic region to compressive buckling region. The authors carried out low cycle fatigue test of deformed bars, and examined the failure criterion of them.
\end{abstract}

